\title{
THE ANALYSIS AND ENVIRONMENTAL PROTECTION MEASURES IN THE MUNICIPALITY OF LAKTAŠI AS A BASIS FOR SUSTAINABLE DEVELOPMENT
}

\author{
Dušica Pešević* ${ }^{* 1}$, Dejan Filipović* ${ }^{* *}$, Svetlana Milošević ${ }^{*}$ \\ "University of Banja Luka - Faculty of Natural Sciences and Mathematics, Banja Luka, \\ Bosnia and Herzegovina \\ "University of Belgrade - Faculty of Geography, Belgrade
}

\begin{abstract}
The Municipality of Laktaši belongs to a group of developed municipalities of the Republic of Srpska. Its development, in addition to the favorable traffic-geographic position and large natural resources, is also determined by noticeable anthropogenic activities that often lead to pollution of the environment. The analysis and assessment of the existing state of environment in the Laktaši municipality represents the basis for its protection and improvement of quality as well as for planning the development of future activities in accordance with sustainable development. Different sources of pollution of the environment are recognized in this area, some of which have significant impacts on the immediate and wider environment. The state of the environment in the work is presented by individual elements (air, water, soil), and the problem of noise and waste is also presented. The article also lists protected natural resources, protection measures are proposed and environmental quality classification was carried out in order to determine the priorities in stopping further degradation of the studied area.
\end{abstract}

Key words: environment, sources of pollution, protection measures, Laktaši municipality.

${ }^{1}$ Corresponding author: D. Pešević, University of Banja Luka - Faculty of Natural Sciences and Mathematics, Dr. Mladena Stojanovića 2, 78,000 Banja Luka, Bosnia and Herzegovina; e-mail: dusica.pesevic@pmf.unibl.org 


\section{Introduction}

The Laktaši municipality, by its natural characteristics and its physicalgeographical position, belongs to the macro-regional complex of the peri-Pannonian rim. It covers a territory of $388 \mathrm{~km}^{2}$ and is located in the central part of the Banja Luka nodal functional region, one of the four nodal-functional regions of the Republic of Srpska. According to the final results of the 2013 census, 34,210 inhabitants live in the area of this municipality in 37 inhabited places. The average population density of Laktaši municipality amounts to 88.2 pop. $/ \mathrm{km}^{2}$, which is about $46 \%$ more than the average population density of The Republic of Srpska. The municipality of Laktaši borders with the town of Banja Luka and four municipalities of The Republic of Srpska: Gradiška, Srbac, Prnjavor and Čelinac. The municipality has an extremely favorable geographic position with regard to the significant infrastructure corridors built over its territory, proximity to Banja Luka as the largest city of the Republic of Srpska and to the border with the Republic of Croatia, that is, the European Union. Through the municipality of Laktaši there is the highway Banja Luka - Gradiška, as well as the Banja Luka - Doboj highway, and on the territory of this municipality there is also the airport Mahovljani, the only international airport of the Republic of Srpska. Existing traffic infrastructure represents a significant potential for further development of this municipality.

Orographically, in the central and northern parts, the low relief of the Lijevče field and the low terraces of Vrbas and its tributaries prevails, while the lower parts of the municipality stretch the low mountains and the hilly forms of relief. The average altitude of the Laktaši municipality is $125 \mathrm{~m}$, with the lowest point of Gornja Ada in the Vrbas valley at $105 \mathrm{~m}$ above sea level and the highest peak of the municipality is Crni Vrh with an altitude of $546 \mathrm{~m}$. The Lijevče field with its flatness represents the most valuable area of the Laktaši municipality, especially in agrarian sense.

Laktaši municipality has significant water resources, is rich in surface water (dense river net, oxbow lakes and small artificial lakes), as well as underground water (thermal and thermo mineral water, and underground reservoir in the Lijevče field alluvium). River Vrbas, as the main municipality water flow, passes through its central part in the length of $44 \mathrm{~km}$ and creates a natural border between Župa and Lijevče. The surface waters of the municipality are also left tributaries of Vrbas: Bukovica, Klašnička river, Mahovljanska river and Osorna, while the right tributaries are Turjanica, which is made up of Vukešnica and Slatinski creek, Crkvena with several smaller streams and Gumjera. 
The municipality of Laktaši belongs to the most intensive development area of RS, Banjaluka-Laktaši-Gradiška, which makes an almost conjugated urban-rural continuum. All the activities and development processes that are present in the Laktaši municipality, existing potentials, but also certain constraints on development, are manifested by certain impacts on closer or wider environment. Based on an analysis of the present state, i.e., natural and anthropogenic factors, certain environmental impacts, i.e., water and air pollution, soil degradation, noise problem and waste management problem have been identified (Filipović, \& Obradović, 2008).

\section{Previous research}

Today's environmental problems are increasingly complex and new scientific approaches and tools are needed to achieve sustainable solutions to protect the environment and public health (Burke et al., 2017). It is known that various human activities have numerous negative environmental impacts (Huckle \& Martin, 2014). Energy requirements are increased, the amounts of different waste materials are on the rise, and the pressure on the quality of water, air and soil is growing. Changes in land use can affect air, land and water quality and, consequently, human health (Stevenson et al., 2016; Mueller et al., 2017). Environmental scientists usually define environmental problems, their decision criteria, collect data and offer an optimal solution (Cynthia Stahl, 2014; Gulia et al., 2015). In order to cope with growing pressure, it is necessary to integrate diverse information on individual environmental mediums and to recognize the inextricable link between their quality and human health (Graff Zivin \& Matthew, 2013; Zeyer \& Dillon, 2014; Guerreiro et al., 2014). These problems from the field of environmental protection are increasingly becoming global problems, but their solution must start from the local level and respect the basic principles of sustainable development (Wittmayer et al., 2016).

Continuous monitoring of water quality is carried out in the studied area of the municipality of Laktaši, while the quality monitoring system has not yet been established for the quality of air and soil. In the wider area of the agricultural area of Lijevče field, a dedicated analysis was carried out for the preparation of studies on the impact of agriculture on the quality of drained waters and groundwaters (Agricultural Institute of the Republic of Srpska [AIRS], 2009; Project, 2009). Considering the fact that the construction of a section of the Banja Luka-Doboj highway is currently under way in the 
municipality, the impact of the bridge construction site in the Miloševac settlement on the quality of the Vrbas and Crkvena rivers was analyzed and a comparison of the parameters analyzed with the situation prior to the commencement of the construction was carried out (Pešević \& Knežević, 2017). In the previous period, no paper on the state of the environment of the municipality of Laktaši was published, in which the analyzes of all elements of the environment, the main drivers of changes, i.e., pressure on their quality, were integrated, nor were protection measures considered.

\section{Existing state of the environment}

It is well known that a healthy environment and good communal infrastructure have a direct impact on the quality of life and human health. The Laktaši municipality area, from a standpoint of the environment, represents a very complex and partly degraded environment. In the structure of land, according to official data (Стратегија развоја општине Лакташи, 2014) agricultural land takes two thirds of the territory of the municipality, while arable land takes as much as $88.96 \%$ of agricultural land, i.e., $57.88 \%$ of the territory of the municipality, which in the earlier period defined agriculture as one of the most important branches of economy. However, according to the economic data, the importance of agricultural production has decreased lately in the economic structure of the municipality and other branches of the economy are being developed: trade, industry (food, electrical, metal, woodworking), construction, gravel, sand and stone exploitation, and design and engineering services (Table 1).

The impact of production processes on the environment goes in three directions: exploitation of natural resources, occupying land by buildings, i.e., alteration of their purpose and appearance of landscaping and as a third - polluting the environment with various waste materials (liquid, solid and gas). As the potentials of municipalities direct the economic development towards the food industry and tourism, it is clear that the preservation of the environment is a prerequisite for the long-term development of the municipality. 
The Analysis and Environmental Protection Measures in the Municipality of Laktaši as a Basis for Sustainable Development

Table 1 - List of registered polluters in the municipality of Laktaši

\begin{tabular}{|c|l|c|c|l|c|}
\hline No. & Name of polluter & $\begin{array}{c}\text { Total } \\
\text { number }\end{array}$ & No. & Name of polluter & $\begin{array}{c}\text { Total } \\
\text { number }\end{array}$ \\
\hline 1. & Animal farms & 18 & 12. & Gas stations & 21 \\
\hline 2. & Slaughterhouses & 10 & 13. & Sawmills & 16 \\
\hline 3. & $\begin{array}{l}\text { Slaughterhouses } \\
\text { with meat industry }\end{array}$ & 1 & 14. & $\begin{array}{l}\text { Warehouse of } \\
\text { hazardous material }\end{array}$ & 2 \\
\hline 4. & Fishpond & 3 & 15. & Wood industry & 2 \\
\hline 5. & Concrete plant & 6 & 16. & Textile industry & 1 \\
\hline 6. & $\begin{array}{l}\text { Separation of stone } \\
\text { and gravel }\end{array}$ & 3 & 17. & $\begin{array}{l}\text { Construction } \\
\text { materials industry }\end{array}$ & 1 \\
\hline 7. & Stonecutter & 2 & 18. & Meat industry & 2 \\
\hline 8. & Sewer discharge & 6 & 19 & $\begin{array}{l}\text { Oil and lubricants } \\
\text { industry }\end{array}$ & 1 \\
\hline 9. & Car junkyard & 8 & 20. & Electrical industry & 3 \\
\hline 10. & $\begin{array}{l}\text { Illegal garbage } \\
\text { dumps }\end{array}$ & 5 & 21. & Food industry & 2 \\
\hline 11. & Printing shop & 2 & 22. & Metal industry & 1 \\
\hline
\end{tabular}

Source: Department for Spatial Planning of the Administrative Office of the Municipality of Laktaši

\section{Water pollution}

The main water polluters in the Laktaši municipality area are untreated wastewater from households, untreated industrial water, drained water from agricultural production and from landfills. In parts of Laktaši, Slatina and Trn settlements there is only a partially constructed sewage network, but no purification of these fecal waters is carried out, instead they are discharged directly into the Vrbas River.

Other settlements do not have a built sewage system, so wastewater from households is taken to septic tanks, which are often leaky, i.e., they do not meet the basic sanitary criteria and pose a risk of soil and groundwater contamination. Major waterborne pollutants are also industrial plants that discharge their wastewater most often without any treatment. The presence of industrial wastewater and those from households in the same collector system makes it much more difficult to protect natural water because of introduction of toxic substances that prevent action of aerobic organisms, but also lead to endangering of ecosystem and biodiversity (Khan, Bhawana, Fulekar, 2013). 
According to the Regulation on Water Classification and Watercourse Categorization ("Official Gazette of the Republic of Srpska" No. 42/2001), the watercourse of the Vrbas River (on the whole length of the river, and thus the Laktaši municipality) is classified in the second category. Other watercourses in the Laktaši municipality are classified into the first category, whose water needs to have high quality status.

On the territory of the municipality of Laktaši, tests of the physicchemical parameters of the Vrbas River at the location Razboj, within the framework of International Monitoring, are carried out by the Public Institution "Vode Srpske" from Bijeljina, which tests the status of water quality of all the major watercourses of the Republic of Srpska. According to the latest available report, 2014 Water Quality Monitoring in the Republic of Srpska at the mentioned site Razboj, there can be observed elevated concentrations of total suspended matter in all eight series of tests (values ranged within the third, fourth and fifth grades of water quality, instead of the recommended first), as well as total phosphorus (in as many as six out of a total of eight test series). (Воде Српске, 2014). The suspended matter is not dissolved in the aqueous sample and is usually of mineral origin (due to the erosion of the bottom and the lateral slants in the flow) and can be covered with organic material. The increase in phosphorus in water can be due to land erosion, where long-term use of mineral fertilizers in agricultural production is present, as well as inadequate treatment of wastewater rich in detergents. Excess phosphorus can cause water eutrophication, especially in the presence of large amounts of nutrients. Such a rapid growth of vegetation in abnormal quantities is accompanied by a reduction of oxygen content in water due to its consumption by dead biomass degradation.

A large amount of waste water emanates from the slaughterhouses, which the area of this municipality, according to the list of registered polluters of Laktaši municipality, has 11 (along with the slaughterhouse which also has a meat industry). However, their total number is much higher, because according to information from the field, a greater number of slaughterhouses have no regulated status. It is well known that sludge from the slaughterhouse contains blood, fat, feces, unprocessed stomach contents and detergents. These wastewaters are heavily loaded with organic matter, fat, nitrogen, phosphorus and oils and fats (Table 2). Therefore, these are very problematic waste streams, which, if not adequately purified, present great danger to surface and groundwater. Discharge of untreated wastewater from slaughterhouses can cause serious threats to recipients, and change the quality of surrounding waters and soil (Matheyarasu et al., 2015). Bioaccumulation 
and biomagnification of pollutants in fish present in watercourses that serve as recipients for waste water from slaughterhouses can affect the entire cycle of the food chain and pose serious threats to domestic flora and fauna. In addition to liquid waste, solid waste material from numerous slaughterhouses of the area is often thrown (unloaded) on the shore or directly into Vrbas.

Septic tanks and landfill sites, as well as wastewater from livestock buildings, represent additional point pollutants of surface and ground waters of the subject area. This is therefore more significant because most villages use groundwater for drinking and should be aware that due to inadequate treatment of septic tanks, stables and cattle manure, pollution of well water can occur. An additional problem affecting groundwater quality and land degradation are illegal landfills caused by abandoned gravel pits. Some abandoned gravel pits have been transformed into manure collectors and other waste materials from farms or slaughterhouses and are subjected to a natural process of water exchange (by groundwater flowing in and out). It is clear that all organic waste directly filters out polluting groundwater. The protective surface layer of watertight clay is very often degraded and removed by technical works (fishponds and gravel pits) so that the waste material is deposited directly into the groundwater of the upper aquifer, which is precisely the water used by the rural population for drinking and irrigation of agricultural land. In order to address this problem, besides the rehabilitation of these illegal landfills, recultivation of devastated surfaces also has to be carried out.

Table 2 - Mean values of concentrations of hazardous and harmful substances in wastewater of slaughterhouse

\begin{tabular}{|l|c|c|c|}
\hline Parameter (unit) & $\begin{array}{c}\text { Slaughter } \\
\text { of pigs }\end{array}$ & $\begin{array}{c}\text { Large cattle } \\
\text { slaughter }\end{array}$ & $\begin{array}{c}\text { Mixed } \\
\text { slaughterhouses }\end{array}$ \\
\hline BPK5 (mg/l) & 1250 & 2000 & - \\
\hline HPK (mg/l) & 2500 & 4000 & $1000-3000$ \\
\hline Suspended matter (mg/1) & 700 & 1600 & $400-800$ \\
\hline Total nitrogen (mg/1) & 150 & 180 & $<300$ \\
\hline Total phosphorus (mg/1) & 25 & 27 & $<10$ \\
\hline Oils and fats (mg/1) & 150 & 270 & $<350$ \\
\hline pH & 7,2 & 7,2 & $7-8.5$ \\
\hline
\end{tabular}

Tehničke upute: Prehrambena industrija: Sektor: Klanje krupne stoke, Federalno ministarstvo okoliša i turizma, Sarajevo, 2008 
The use of pesticides and artificial fertilizers represents the largest source of pollution within the dispersed sources of groundwater pollution. Given the long-term use of agrochemicals in the Lijevče field for the needs of intensive agricultural production, there was a need for certain researches that established the contents of pesticide residues and nitrates in the drainage waters of agricultural land Lijevče field (AIRS, 2009) as well as a need for research on the influence of pesticides on groundwater of Lijevče field (Projekt, 2009). The results of these studies have shown that the nitrate content in all the drains was above the permissible concentrations, thus confirming that drainage water contains hazardous and harmful substances that originate from agricultural production. Also, all the measurements of the samples of drainage waters found the residues of one or more pesticide compounds (AIRS, 2009). The investigation of the presence of residues of pesticides in groundwater has established their presence in five locations (most at the place of sampling Aleksandrovac - concentration $0.22 \mu \mathrm{g} / \mathrm{l}$ ) and even where the hydrogeological environment is defined as less vulnerable due to the hydrogeological characteristics (Projekt, 2009). These findings suggest that the influence of pesticides on groundwater depends directly on the way pesticides are used and the concentrations used.

\section{Air pollution}

Regarding the nature of the pollution, surface, point and line pollution sources can be singled out. Air pollution is a result of intensive traffic (Kumar et al., 2015), the process of warming individual houses, business and public space, as well as emissions from business entities, emissions from illegal landfills and from agricultural activities (Lelieveld et al., 2015). Although we can conclude that the effects of pollution are relatively small, over the last few years there has been an increased line of air pollution due to the increased traffic of motor vehicles through the Laktaši municipality. The reason for this is the emission of pollution from motorway Gradiška - Banja Luka, then the traffic on the main road passing through the center of Laktaši, where frequent traffic congestion and emission of a large amount of air pollution into the air is present. Additional emission to the air is the construction of the Banja Luka -Doboj highway that passes through this municipality. The most important point sources of air pollution in this area are industrial plants. There are three industrial zones in the Laktaši municipality. The first is located in the town of Laktaši, about a kilometer away from the center of the settlement. In this zone there are industrial plants for food, meat, electrical industry, press shops, as 
well as concrete plants and separation of rock and gravel, which emit large quantities of dust and other aerosols into the air. The other zone is Aleksandrovac, which is still being formed as an agricultural and business park, and until now only the food industry (Banjaluka Dairy, Sima Trejd etc.) has been built. The third zone is in the Veliko Blaško settlement, consisting of several sawmills and concrete plants. Speaking of that, according to the list of registered polluters in the municipality of Laktaši, 16 sawmills, 6 concrete plants and 3 separations of stone and gravel are registered. It is a worrying fact that the largest number of polluters is located in the most densely populated part of the municipality, along the main road Banja Luka - Gradiška and that this pressure of population and activities in the environment can lead to disturbance of the ecological balance in this area.

In the Laktaši municipality there is no continuous measurement of air quality. Given the lack of adequate data on emissions and the introduction of air pollutants, it is impossible to talk with certainty about its quality. However, with regard to the deployment of the aforementioned anthropogenic activities which emit various air pollutants, especially in the winter period due to higher consumption of fossil fuels for heating, as well as the occurrence of temperature inversion and fog, air quality is most endangered in Laktaši settlement and other larger settlements (especially Trn), while in other parts of the municipality, air quality is relatively conserved.

\section{Soil pollution}

Soil pollution, according to the most commonly used definition, is the introduction of substances and/or energy into the soil that can endanger human health, have a negative impact on living organisms and the environment, damage the structure of soil or are in any way contrary to the legal regulations from the area environmental protection. Direct sources of pollution of soil in the Laktaši municipality are inadequate application of mineral fertilizers and pesticides, landfill sites and wild landfills, as well as indirect sources of pollution like septic tanks, traffic, industrial plants, boilerhouses and fireplaces.

A special problem in the Laktaši municipality is uncontrolled urbanization that deprives high-quality land resources for agro-production. Much of the fertile land is covered by houses, buildings, farms, roads, airports, and the like, so urban facilities practically squeeze agricultural complexes of this area and degrade it by polluting it in different ways. One should not lose sight of the fact that every year in the Republic of Srpska, about 1500-2000 ha 
of agricultural land transforms into non-agricultural purposes (The government of the Republic of Srpska, 2016). The process is particularly focused on the quality of land suitable for different aspects of agricultural activity.

Additional causes of the loss of fertile agricultural land of this municipality are the meandering of the Vrbas river stream, downstream from the Laktaši settlement, and the uncontrolled exploitation of gravel and sand on the banks and open fields, which has been going on for decades. As mentioned above, after the cessation of the abovementioned exploitation, abandoned mines are often transformed to illegal landfills, which is an additional pressure on soil as well on water pollution (Maglajani, Krnete, Kobatovci, Mrčevci).

\section{Waste management problem}

Municipal waste collected in the municipality of Laktaši is deposited at the regional landfill "Ramići" near Banja Luka, which is $29 \mathrm{~km}$ from the city center of Laktaši. According to the data of the public company "DE-POT", established in 2003 with the aim of sanitation and expansion of the existing landfill, the quantity of waste brought from the Laktaši municipality area in 2016 was 8,320 tons, $93 \%$ of which was mixed communal waste $(7,748 t)$. In addition to communal waste, landfill is also obliged to accept animal waste as there is currently no other adequate method of permanent disposal of this type of waste. There are significant capacities in the area of the municipality for the production and processing of meat, which produce large amounts of slaughterhouse waste. According to the existing data (Општина Лакташи, 2012), 20 tons of slaughterhouse waste from slaughterhouses and farms (plus mortality from livestock farms) are generated daily in the Laktaši municipality area. Disposal of slaughterhouse waste into municipal waste disposal sites is not in accordance with the standards applicable to sanitary landfills (Pešević, 2016 a), but the health-hygienic aspect and potential environmental pollution is more acceptable way of solving this problem than the one practiced by individual producers and households, which is the disposal of slaughterhouse waste on river banks and illegal landfills (Regionalna strategija ruralnog razvoja opština Gradiška, Kozarska Dubica, Laktaši i Srbac za period 2012 - 2015. godine, 2012).

In Laktaši municipality, there is also a problem of other types of waste, such as sawdust from a total of 13 sawmills and old cars from 8 car waste. The production capacity of the wood industry in the Laktaši municipality is about $100,000 \mathrm{~m}^{3}$ /year and the wood waste amounts to $25-30000 \mathrm{~m}^{3} /$ year, 
which is a significant source of raw materials for the production of pellets and other products. Some rural parts of the municipality are not covered by the waste collection system, which leads to the creation of illegal landfills, most often near the villages or abandoned stone and gravel pits.

\section{The noise problem}

Continuous noise measurement is not performed in the Laktaši municipality. Like in most other cities, the strongest noise is generated near the road and industrial plants. As part of the study of the impact on environment of the E-661 highway Gradiška - Mahovljani, traffic noise calculations were carried out along this traffic route. The obtained competent levels indicate that, at a reference distance of $25 \mathrm{~m}$, the noise level during the day would be around 76 $\mathrm{db}(\mathrm{A})$ and around $66 \mathrm{db}(\mathrm{A})$ during the night. Due to the considerable loads with relatively elevated noise levels, along this highway, near the town of Laktaši, the safety belts were erected. A high noise level is also present along the main road Banja Luka - Gradiška, which passes through the very center of the town of Laktaši. The highway that is still built on the Banja Luka - Doboj route, and crosses the territory of the Laktaši municipality, will also represent a stress on the environment with an increased noise level. An additional source of noise is related to the Laktaši airport as planes and helicopters often cause noise of more than 100 decibels. At present, the number of landings and take-offs from this airport is minimal, but given the expected higher frequency of flights in the future, adequate noise protection measures will need to be provided. Thus, in some areas of the Laktaši municipality there is a high level of noise, which requires its continuous measurement and, in cases of intensification, introduction of adequate noise protection measures.

\section{Protected natural resources}

The Government of the Republic of Srpska recently declared a protected forest complex near Slatina spa as Forest Park "Slatina" (Official Gazette of The Republic of Srpska, No. 67/16), which represents a combination of natural and manmade resources on the surface of 35.73 hectares. It is characterized by biodiversity in urban environment, great landscape value, favorable morphological characteristics of the terrain which enable the use of space for leisure and recreation, the wealth of hydrology, the attractiveness of the broader and narrower area, and the ease of accessibility. Much of the 
complex consists of preserved natural forest stands of beech and oak, while the smaller part is artificially formed stand of black pine trees aged about 70 years old, which has already become the trademark of Slatina settlement. Apart from its natural values, Slatina has a significant cultural and historical heritage. The thermal springs of thermal water in the Slatina park and facilities are also placed on the Provisional List of National Monuments of Bosnia and Herzegovina. According to the Spatial Plan of Republic of Srpska until 2025, another nature park according to the IUCN classification should be established, and that is Laktaši Bathing Complex. According to the Strategy of Development of Laktaši Municipality until 2016, the plan is to establish the "Starača" fishing zone with the promenade in Laktaši, the nature park "Jelića brdo" in Laktaši, the forest park "Borik - Carev potok" in Slatina and the protection of valuable trees, forest stands and habitats in the municipal area.

\section{Categorization of the environment in the municipality of Laktaši}

The area of the Laktaši municipality presents a complex structure from the aspect of environmental protection. The town is characterized by the most concentrated ecological problems, network secondary locations are characterized with different levels of ecological problems and parts of the municipality with a relatively preserved natural environment. In accordance with the European Union standards and experiences, the environment and planned trends for the next period, the paper presents the geospatial categorization of the environment according to the pollution and the anthropogenic degradation or threat to the quality of the environment of the Laktaši municipality (Filipović, Obradović, 2008; Pešević, 2016 b).

Using the methodology of agro-ecological zoning and GIS modeling based on the GIS database (pedological cover, soil usage method, layout and size of settlements, industry, water resources, traffic infrastructure) (Pešević, 2016 b) Figure 1 shows the synoptic map of categorization of the environment quality of the Laktaši municipality. In addition to the mentioned database, for the cartographic representation of environmental categorization, the interaction of complex systems that exist in this area and which have a significant impact on the quality of the environment have been considered. 
The Analysis and Environmental Protection Measures in the Municipality of Laktaši as a Basis for Sustainable Development

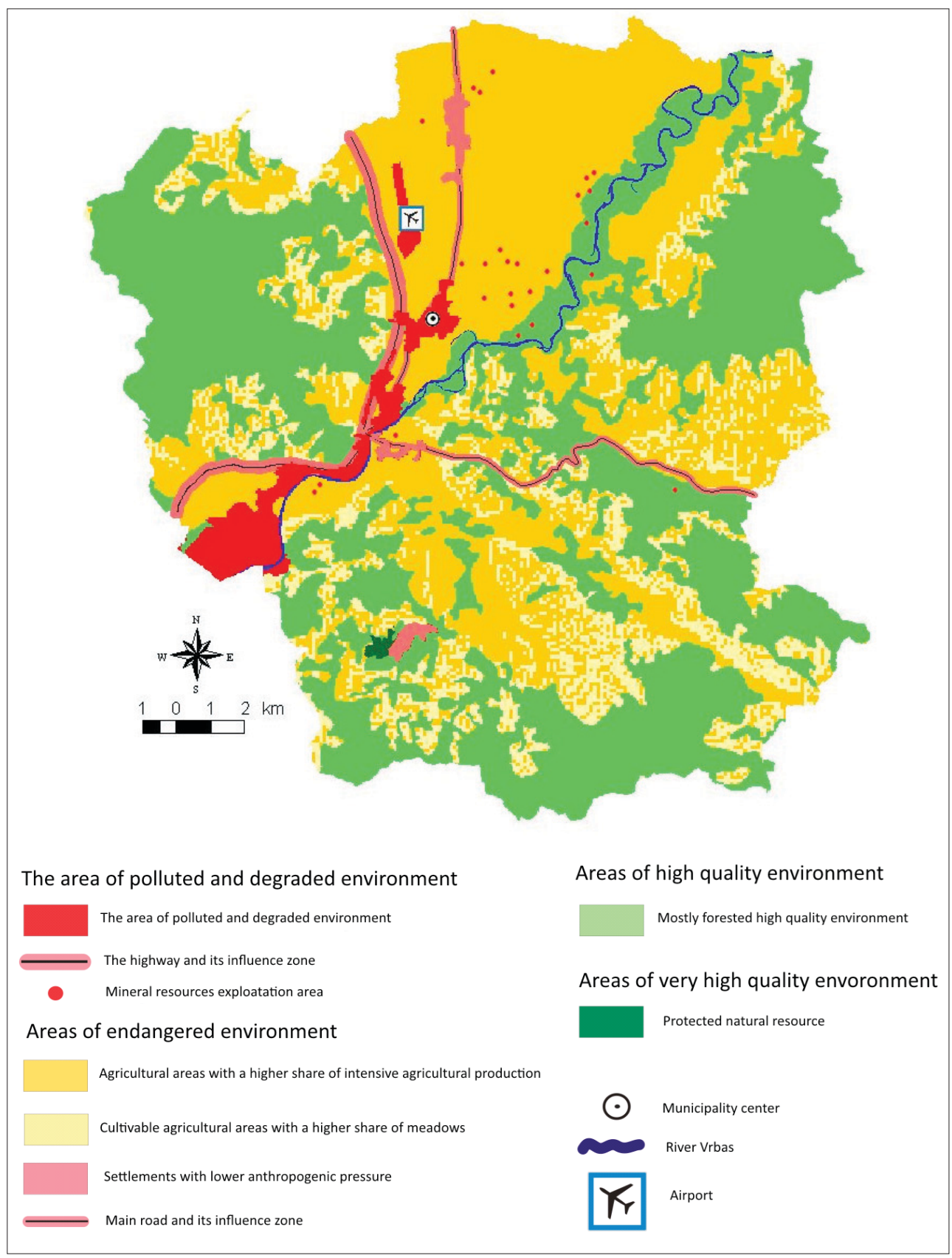

Figure 1 - An overview map of the categorization of the state of the environment of the municipality of Laktaši geospatial area 
Taking into account the natural conditions and the man built environment in the municipality of Laktaši, four areas (categories) of the environment can be distinguished according to the specificities of the following spatial units (Figure 1):

1. Areas of polluted and degraded environment - the area with the highest number of polluters and the highest concentration of population. This area includes the town center of Laktaši, the Trn area with an industrial zone, an airport, a highway and its area of influence, as well as areas of exploitation of mineral resources some of which have turned into illegal landfills.

2. The areas of the endangered environment include two sub-categories, namely:

a) cultivated agricultural areas with a higher share of intensive agricultural production and greater use of agrochemicals,

b) cultivated agricultural areas with a larger share of meadows, i.e., lower intensity of agricultural production and lower utilization of agrochemicals.

Settlements with fewer population compared to the urban settlement Laktaši and Trn (Slatina, Aleksandrovac and other settlements along the main road Banja Luka - Gradiška) and the zone of influence of the arterial road are included in this area.

3. Areas of high quality environment that is mostly covered by forests.

4. Areas of very high quality environment representing a protected forest complex near Banja Slatina, called Forest Park "Slatina".

\section{Measures to protect and improve the environment}

The definition of the protection measures aims to reduce environmental impacts within the limits of acceptability or contribute to the prevention, reduction or elimination of any significant adverse impacts on the environment (Filipović \& Obradović, 2008). Measurement mechanisms should be set to allow monitoring of environmental pollution changes in order to take timely action to address acute problems that may appear, as well as measurement of the results of implemented projects and measures to protect the environment. 
The Analysis and Environmental Protection Measures in the Municipality of Laktaši as a Basis for Sustainable Development

Measures for the protection of water

- Reconstruction, construction and rehabilitation of the existing water supply network, and construction of rural waterworks;

- Design of a sanitary protection program for all public sources used for water supply; and the establishment of the sanitary protection zone for Laktaši spa and marking the sanitary protection zone of the source of thermal water in Slatina;

- Construction and equipping, i.e., commissioning of sewage treatment plants (especially sewage that originate from industrial plants);

- Implementation of municipal separate sewage systems for separation of run-off waters from wastewaters;

- -Reconstruction of existing and construction of new sewage networks in urban settlements;

- Sanitation of rural settlements, with drainage of household wastewater into the proper waterproof septic tanks, with the organization of further wastewater treatment in a sanitary safe manner;

- Realization of a complete flood protection system in vulnerable areas;

- Monitoring and control of drinking water, in particular for the presence of pesticides, heavy metals, detergents and the like.

\section{Air protection measures}

Air protection should be achieved by undertaking measures to systematically monitor air quality, reduce air pollution below imposed introduction limit values, take technical, technological and other measures to reduce emissions, and monitor the impact of polluted air on human health and the environment:

- Dislocate transit traffic of heavy vehicles from the city center, which will transform part of the main road to the city street network;

- Establish monitoring of air quality monitoring of basic pollutants, and periodically measure specific pollutants from traffic and industrial facilities,

- Introduce incentives for the use of renewable energy sources in buildings;

- Make a study on the district heating of the Laktaši settlement; 
- Conduct research about and use geothermal energy for energy and production purposes;

- Develop cycling and pedestrian traffic in the municipality;

- Plant trees and increase green areas and parks in urban areas of the municipality.

\section{Land protection measures}

- Stopping uncontrolled reduction of agricultural land (especially illegal construction of buildings)

- Prevention of soil pollution due to the discharge of untreated waste waters and lack of waste management systems;

- Reparation of wild landfills and degraded areas throughout the municipality;

- Reduction and control of use of agrochemical agents and gradual replacement with less toxic substances;

- Protect land from wastewater and aerosols;

- Preventing uncontrolled exploitation of gravel and sand on shore and open fields;

- Sanitation and recultivation of abandoned gravel pits;

- Application of land monitoring to the content of hazardous and harmful substances.

\section{Protection measures regarding waste}

- Collection of waste throughout the whole municipality;

- Formation of a large number of green islands for sorting waste by sorts;

- Training and technical equipment of municipal utility service for selective collection and recycling of waste;

- Development of technological processes that use secondary raw materials in the production process;

- Separation of hazardous and non-hazardous waste at source;

- Construction of a recycling yard, as well as enclosed "boxes" where the population would lay bulky waste, all in order to maximally avoid waste disposal practices at sites which are not intended for that; 
The Analysis and Environmental Protection Measures in the Municipality of Laktaši as a Basis for Sustainable Development

- Construction and functional equipping of slaughterhouse waste processing facilities;

- Use of waste for energy production using new technologies (especially wood waste);

- Sanitize illegal landfills and sanction their creation through enhanced inspection of competent municipal authorities;

- Raise ecological awareness of citizens and business entities about the harmfulness of improper disposal of waste.

\section{Noise protection measures}

- Determination of the exposure level of noise to human health and the environment on the basis of domestic and internationally accepted standards;

- Appropriate technical and non-technical noise protection measures, in accordance with the noise level excess, taking into account the provisions of the Rulebook on permitted limits of sound and noise intensity(Official Gazette of SR BiH, No. 76/89).

Measures for the protection of natural resources, vegetation and ecologically valuable areas

- Strong respect of the Law on Nature Protection (Official Gazette of The Republic of Srpska No. 50/02) and Environmental Protection Act (Official Gazette of The Republic of Srpska, No. 28/07), which form the basis of the legal framework for the protection of natural values;

- Introduction and consistent implementation of the principle of protection of natural resources and general nature protection in the planning process;

- Promotion of the Principle: "Every use of nature and its load shall be carried out in a manner that minimizes pollution or damages nature".

\section{Conclusion}

In the analysis of the environment situation of the Laktaši geospatial area, complexly contemplated modern processes of urbanization, industrial development, traffic and agricultural production have been taken into ac- 
count. In the area of the municipality of Laktaši, the problems of the sewage network deficiencies, the lack of primary and secondary collectors and wastewater treatment facilities, the lack of availability and the lack of connectivity of public water supply systems in rural areas, and the lack of infrastructure necessary for proper waste management (especially slaughterhouse and wood waste) are highlighted. An analysis of the existing environmental situation in the territory of the municipality of Laktaši showed that this area represents a very complex and partly degraded environment, within which four areas (categories) of environmental quality can be distinguished (based on dominant anthropogenic activities and interaction of complex systems that exist in this space, which have a significant influence on the quality of the environment). Cartographic representation of environmental quality grading facilitates the prioritization of measures to adequately protect, preserve and improve the quality of the geographic environment of the studied space, as well as procedures and programs for the rehabilitation of the degraded environment. The planning of future development at all levels must be based on the principles of sustainable development, which implies the rational use of natural resources: water, soil, mineral resources and all other natural resources, while preserving and improving the ecological potential of space (Filipović, \& Obradović Arsić, 2010). In order to minimize and eliminate possible changes and adverse impacts on the environment, it is necessary to apply the proposed protection measures and establish measurement mechanisms that will allow for monitoring of environmental pollution changes in order to take timely action to address the acute problems that may arise in time.

\section{References}

Agricultural Institute of Republika Srpska (2009). Testing of the content of pesticide residues and nitrates in drainage waters of agricultural land. Banja Luka: Agricultural Institute of Republika Srpska

Burke, T.A., Cascio, W. E., Costa, D. L., Deener, K., Fontaine, T. D., Fulk, F. A., Jackson, L.E., Munns, W. R., Orme-Zavaleta, J., Slimak, M. W. \& Zartarian V.G. (2017). Rethinking environmental protection: meeting the challenges of a changing world. Environmental Health Perspectives, 125 (3), doi:10.1289/ EHP1465, https:/ / www.ncbi.nlm.nih.gov/pmc/articles/PMC5332174/

Federalno ministarstvo okoliša i turizma (2008). Tehničke upute: Prehrambena industrija: Sektor: Klanje krupne stoke. 
Filipović, D., \& Obradović, D. (2008). Analysis of the situation and environmental protection measures in the Subotica municipality as a basis for the sustainable development strategy of this area. Bulletin of the Serbian Geographical Society, 88 (3), 61-72

Filipović, D., \& Obradović - Arsić, D. (2010): Analysis of the environmental state in the municipality Grocka as a basis of integrated planning protection. Bulletin of the Serbian Geographical Society, 90 (3), 171-188.

Government of Republic of Srpska (2016). Decision on the Declaration of Park forest "Slatina" Banjaluka: "Official Gazette" of Republic of Srpska 67/16.

Graff Zivin, J., \& Neidell, M. (2013). Environment, Health, and Human Capital. Journal of Economic Literature, 51(3), 689-730. http://www.jstor.org. ezproxy.ub.gu.se/stable/pdf/23644825.pdf

Guerreiro, C. Foltescu, V., \& Leeuw, F. (2014). Air quality status and trends in Europe, Atmospheric Environment, 98, 376-384. https:/ / doi.org/10.1016/j. atmosenv.2014.09.017

Gulia, S., Nagendra, S., Khare, M., \& Khanna, I. (2015). Urban air quality management - A review. Atmospheric Pollution Research, 6 (2), 286-304.

Huckle, J., \& Martin, A. (2014): Environments in a Changing World. New York: Routledge.

Khan, R., Bhawana, P., \& Fulekar, M. H. (2013). Microbial decolorization and degradation of synthetic dyes: a review. Reviews in Environmental Science and Bio/Technology, 12 (1), 75-97. https:/ / doi.org/10.1007/s11157-012-9287-6

Kumar, P. Morawska, L., Martani, C., Biskos, G., Neophytou, M., Di Sabatino, S., Bell, M., Norford, L., \& Britter, R. (2015). The rise of low cost sensing for managing air pollution in cities. Environment International, 75, 199-205. http:/ / dx.doi.org/10.1016/j.envint.2014.11.019

Lelieveld, J., Evans, J. S., Fnais, M., Giannadaki, D., \& Pozzer, A. (2015). The contribution of outdoor air pollution sources to premature mortality on a global scale. Nature, 525, 367-371. doi:10.1038/nature15371

Matheyarasu, R., Seshadri, B., Bolan, N.S., \& Naidu, R. (2015). Impacts of Abattoir Waste-Water Irrigation on Soil Fertility and Productivity, Irrigation and Drainage - Sustainable Strategies and Systems, InTech, doi: 10.5772/59312

Mueller, N., Rojas-Rueda, D., Basagaña, X., Cirach, M., Cole-Hunter, T., Dadvand, P., Donaire-Gonzalez, D. Foraster, M., Gascon, M., Martinez, D.,Tonne, C., Triguero-Mas, M., Valentín, A., \& Nieuwenhuijsen, 
M. (2017). Health impacts related to urban and transport planning: A burden of disease assessment. Environment International, 107, 243-257. https:/ / doi.org/10.1016/j.envint.2017.07.020

"Official Gazette" of Republika Srpska (2001). Decree on the classification of water and categorization of waterflow "Official Gazette" of Republika Srpska 42/2001. Banjaluka: “Official Gazette” of Republika Srpska.

Pešević, D., \& Knežević, N. (2017). Impact of the construction site of a part of the Banjaluka - Doboj motorway on the quality of water in the rivers Vrbas and Crkvena. Archives for Technical Sciences, 17, 99-106. doi: 10.7251/ afts.2017.0917.099P

Pešević, D. (2017 a). Assessment of the situation and identification of problems in the waste management system in the Republic of Srpska. Proceedings on the occasion of the 20th anniversary of the work of the Faculty of Natural Sciences and Mathematics, University of Banja Luka, 163-173.

Pešević, D. (2016 b): Geospatial differentiation of the Banjaluka region environment, Journal of Environmental Sciences, 4(1), 23-32.

Project (2009). Study on the impact of pesticides on groundwaters of Lijevče field. Banja Luka: Project.

Public Institution Institute for Urban Planning, Civil Engineering and Ecology of Republic of Srpska.(2016). Spatial plan of the municipality of Laktasi. Draft.Banjaluka: Public Institution Institute for Urban Planning, Civil Engineering and Ecology of Republic of Srpska.

Regionalna strategija ruralnog razvoja opština Gradiška, Kozarska Dubica, Laktaši i Srbac za period 2012 - 2015. godine http:/ / www.kozarskadubica. org/Oglas/81STATEGIJA_RAZVOJA_nacrt_mart\%202012.pdf

Republika Srpska Institute of Statistics (2017). Census results 2013, Cities, municipalities, settlements. Banjaluka: Republika Srpska Institute of Statistics.

Stahl, C.H. (2014). Out of the Land of Oz: the importance of tackling wicked environmental problems without taming them. Environment Systems and Decisions, 34(4), 473-477. https:/ / doi.org/10.1007/s10669-014-9522-5

Stevenson, M., JasonThompson, J., Hérick, T. Ewing, R., Mohan, D., McClure, R., Roberts, I.,Tiwari, G., GilesCorti, B., Sun, X., Wallace, M. \&Woodcock, J. (2016): Land use, transport, and population health: estimating the health benefits of compact cities. The Lancet, 388(10062), 2925-2935. 
The Analysis and Environmental Protection Measures in the Municipality of Laktaši as a Basis for Sustainable Development

Wittmayer, J.M., Steenbergen, F., Rok, A. \& Roorda, C. (2016). Governing sustainability: a dialogue between Local Agenda 21 and transition management. Local Environment, 21(8), 939-955.

Zeyer, A., \& Dillon, J. (2014). Science environment health - Towards a reconceptualization of three critical and inter-linked areas of education. International Journal of Science Education, 36(9), 1409-1411. http://dx.doi.org/10.1080/09500693.2014.904993

Акциони план одрживог енергетског развоја општине Лакташи (Sustainable Energy Action Plan-SEAP). Општина Лакташи, 2012.

Измјене и допуне просторног плана Републике Српске до 2025. године. Урбанистички завод Републике Српске Бањалука, 2013.

Комисија за очување националних споменика Босне и Херцеговине, Привременалистанационалнихспоменика.http://kons.gov.ba/nacionalni_ spomenici/privremena_lista/default.aspx?id=7373\&langTag=en-US

Праћење квалитета површинских водотока у Републици Српској 2014. Воде Српске, Бијељина, 2014.

Стратегије развоја општине Лакташи за период 2014 - 2024. година. Општина Лакташи, 2014.

Студија заштите за проглашење Парк шуме “Слатина”. Републички Завод за заштиту културно-историјског и природног насљеђа Републике Српске. Бања Лука, 2016. 